University of Chicago Law School

Chicago Unbound

Journal Articles

Faculty Scholarship

1976

\title{
Labor Arbitration and Discrimination: The Parties' Process and the Public's Purposes
}

Bernard D. Meltzer

Follow this and additional works at: https://chicagounbound.uchicago.edu/journal_articles

Part of the Law Commons

\section{Recommended Citation}

Bernard D. Meltzer, "Labor Arbitration and Discrimination: The Parties' Process and the Public's Purposes," 43 University of Chicago Law Review 724 (1976).

This Article is brought to you for free and open access by the Faculty Scholarship at Chicago Unbound. It has been accepted for inclusion in Journal Articles by an authorized administrator of Chicago Unbound. For more information, please contact unbound@law.uchicago.edu. 


\title{
Labor Arbitration and Discrimination: The Parties' Process and the Public's Purposes*
}

\author{
Bernard D. Meltzer $\dagger$
}

The literature of labor arbitration has frequently dealt with rival conceptions of the proper role of an arbitrator faced with statutory or public policy issues that are enmeshed with questions arising under the provisions of a collective bargaining agreement. ${ }^{1}$ This article examines that problem in a particular context, namely, when the provisions of Title VII of the Civil Rights Act of 1964, as amended, ${ }^{2}$ overlap or conflict with particular provisions of a collective agreement. ${ }^{3}$

In Alexander $v$. Gardner-Denver Co., ${ }^{4}$ the Supreme Court dealt with that problem and reaffirmed the idea that arbitration is primarily an instrument of the parties' private purposes rather than a means for achieving public purposes reflected in the law of the land. ${ }^{5}$ The drawing of a bright line between private and public pur-

* This article was the basis for a talk delivered on April 22, 1976 at the annual meeting of the National Academy of Arbitrators, held in San Francisco, California. It will appear in the proceedings of that meeting, entitled Arbitration-1976 and to be published by the Bureau of National Affairs, whose permission to publish this article is gratefully acknowledged by the Review.

$\dagger$ James Parker Hall Professor of Law at The University of Chicago and Member, National Academy of Arbitrators. A prior draft of this article benefited from the suggestions of Professor Eileen Silverstein, who naturally bears no responsibility for any errors that follow. The author is also pleased to acknowledge the research assistance of George Curtis, J.D., The University of Chicago, 1976.

' See, e.g., McKelvey, The Presidential Address: Sex and the Single Arbitrator, in arbitration and the Public Interest: Proceedings of the Twenty-Fourth Annual Meeting, National ACademy of Arbitrators 1 (1971); Feller, The Impact of External Law upon Labor Arbitration (to be published in the proceedings of a conference on the future of arbitration, sponsored by the American Arbitration Association). I am indebted to Professor Feller for his courtesy in sending me a prepublication copy of his most helpful paper.

${ }^{2} 42$ U.S.C. $\$ \S 2000$ e to $2000 \mathrm{e}-17$ (Supp. II, 1972), amending 42 U.S.C. $\$ \$ 2000 \mathrm{e}$ to $2000 \mathrm{e}$ 15 (1970).

${ }^{3}$ For a survey of arbitrators' views as to the appropriate role of arbitration in employment discrimination cases, see Edwards, Arbitration of Employment Discrimination Cases: An Empirical Study, in Arbitration 1975: Proceedings of the Twenty-Eighth Annual Meeting, National Academy of Arbitrators 58, 78-81 (1976). See also Edwards, Arbitration of Employment Cases: A Proposal for Employer and Union Representatives, 27 LAB. L.J. 265 (1976). Professor Edwards kindly supplied a prepublication copy of this article.

415 U.S. 36 (1974).

5 Id. at 52-54. See also United Steelworkers of America v. Warrior \& Gulf Navigation Co., 363 U.S. 574, 582-83 (1960); Western Mass. Elec. Co., 65 Lab. Arb. 816 (1975) (Summers, Arbitrator). 
poses in this context may, of course, be criticized as unreal; for arbitrators are surrounded by restraints and values expressed in law and public policy. ${ }^{6}$ Furthermore, the Supreme Court, as it transformed arbitration from the waif of the common law into the darling of our national labor policy, stressed the important public interest in securing the fairness, order, and peace that are the goals of arbitration and no-strike clauses. ${ }^{7}$ Despite this intertwining of public and private purposes, reminiscent of Adam Smith's invisible hand, the dominating fact-and one recognized by Gardner-Denver-is that the parties generally provide and pay for their own arbitration system in order to achieve their own private purposes, as distinguished from those reflected in external law.

Although the Court in Gardner-Denver responded to that fact, it also recognized and legitimated efforts of the parties by express contractual clauses to enforce particular public policies by recourse to arbitration. Specifically with respect to discrimination, the Court understandably did not pause to question agreements that commissioned arbitrators to enforce contractual provisions similar to or duplicative of Title VII and related antidiscrimination programs. ${ }^{8}$

As a purely formal matter, such private endorsement of public policy is wholly consistent with the idea of consent that lies at the core of both collective bargaining and arbitral authority. Furthermore, such endorsement appears to be a welcome symbol of the parties' special sympathy for broad social concerns. Thus the fact that collective agreements increasingly incorporate the proscriptions of Title VII may seem encouraging. But a closer look raises substantial questions about this apparently benign trend.

Such seemingly voluntary endorsement may, it should be noticed, be a response to governmental pressure. Under an OFCC guideline, nonexempt government contractors are to "include nondiscrimination clauses in all union agreements." This guideline does not specifically require that such clauses be enforceable through the arbitration machinery established for other provisions

- See, e.g., McKelvey, supra note 1, at 3, 28. See also Holodnak v. Avco Corp., 381 F. Supp. 191, 204 n.12 (D. Conn. 1974), rev'd in part, 514 F.2d 285, 291-92 (2d Cir. 1975).

' Boys Markets, Inc. v. Retail Clerks Local 770, 398 U.S. 235 passim (1970).

* See 415 U.S. at $52-55$.

- 41 C.F.R. $\$ 60-2.21(a)(7)$ (1971). This guideline also calls for the contractor to "review all contractual provisions to ensure they are nondiscriminatory." The no-discrimination clause to be incorporated in a collective agreement under this guideline is not expressly required to be as detailed or as comprehensive as the "equal opportunity clause" which is generally required to be included in government contracts. See 41 C.F.R. $\$ 60-1.4(a)(1)$ (1971). 
of an agreement. If arbitration were conscripted for the enforcement of public purposes, sobering questions would arise concerning both the resultant benefits to antidiscrimination policy and risks to the classic purposes of arbitration. But quite apart from any direct governmental compulsion, similar risks are present, even though the parties to collective agreements agree voluntarily to contractual provisions paralleling those of Title VII.

In assessing the potential risks and benefits of such voluntary provisions, it is important to distinguish between two types of clauses. The first would seek to insure only that application of all other provisions of the agreement would take account of the nondiscrimination standard. This type of provision would be designed not to expand, but only to inform, arbitral jurisdiction conferred by other specific contractual provisions, such as just cause provisions. The second and more ambitious type of clause would seek to create an independent source of arbitral jurisdiction; for it would not only guide the arbitrator in applying the other specific provisions of the agreement, but would authorize him to invalidate them when repugnant to public law.

The second type of clause is illustrated by the so-called Gardner-Denver clause, proposed at the 1974 meeting of the $\mathrm{Na}$ tional Academy of Arbitrators. In essence, such a clause would (1) include "the broadest possible nondiscrimination clause"; (2) authorize "the arbitrator to apply all applicable law, including Title VII, other federal, state, and local civil rights laws, and court and agency decisions and guidelines"; (3) grant the arbitrator the same authority as a federal court, including authority to rewrite the contract after permitting the parties to negotiate necessary corrections; (4) provide for a special panel of arbitrators, established preferably by the EEOC or, alternatively, with the approval of civil rights organizations; and (5) grant "special procedural protections" for the alleged discriminatee, such as the right to select his own counsel when he is not attacking a provision of the agreement or a construction asserted by the union. ${ }^{10}$ Given such a clause, federal and state courts and fair employment agencies in turn should, it was also

${ }^{10}$ Newman, Post-Gardner-Denver Developments in the Arbitration of Discrimination Claims, in Arbitration-1975: Proceedings of the Twenty-Eighth Annual Meeting, National Academy of Arbitrators 36, 37-38 (1976). See also Basic Vegetable Prods., Inc., 64 Lab. Arb. 621, 624-25 (1975) (Gould, Arbitrator). In regard to the fifth proposed aspect of Gardner-Denver clauses, it could be argued that the alleged discriminatee needs the right to select his own counsel most when he is attacking a provision of the agreement or a construction asserted by the union, since it is in these situations that his interests are most likely to conflict with those of the union which purportedly represents him. 
proposed," adopt a policy of deferring to both the arbitration process and completed awards, similar to the NLRB's policy under Spielberg ${ }^{12}$ and Collyer. ${ }^{13}$

Even if such expansionist proposals were adopted, it is worth noting at once that the Supreme Court is not likely to adopt such a policy of formal deference to awards that, like the one in GardnerDenver, reject claims of individual discrimination. ${ }^{14}$ There the Court, although rejecting any formal rule of deference to such awards, indicated that in proper circumstances they would be entitled to great weight, especially when the issue was solely one of fact. ${ }^{15}$

In addition to the hope of increased deference and the corresponding reduction of multiple litigation, several other considerations lie behind the proposals for Gardner-Denver clauses. First, there is the celebrated ode to labor arbitration composed by the Supreme Court in the Steelworkers trilogy. ${ }^{16}$ Second, there is the notoriously heavy backlog of the EEOC and the federal court system. Third, there is the understandable desire to be "relevant" and to play a role in meeting pressing social needs. ${ }^{17}$ Fourth, Title VII issues are so enmeshed with ordinary grievances that it is feared that arbitral self-limitation with respect to such issues would "decimate the arbitration process." 18

" Newman, supra note 10, at 38.

12 Spielberg Mfg. Co., 112 N.L.R.B. 1080 (1955).

is Collyer Insulated Wire, 192 N.L.R.B. 837 (1971).

14 The Court found that the pertinent legislative history both evinced an intent to preserve the Title VII remedy as a supplement to existing statutory and arbitral remedies and was inconsistent with any requirement of "election of remedies." 415 U.S. at 47-51.

The Court also expressed concern about the suitability of arbitration as a plenary forum for discrimination cases. Id. at 58 n.19. Gardner-Denver clauses are, of course, designed to meet that concern, but they do not eliminate one of its important causes-the veto power exercised by unions and employers, respectively, over the choice of arbitrators. That concern would be alleviated if the alleged victim of discrimination would also have to approve the arbitrator, with the advice of his lawyer or the EEOC. Such arrangements would, however, raise troublesome questions, including these: Could the EEOC expeditiously and competently discharge this additional function? Could individual grievants engage qualified counsel, and how would counsel be paid? Would arbitrators remain more interested in their acceptability to unions and employers than in their acceptability to individual grievants or the guardians of their interests? Notwithstanding such questions, the potential in GardnerDenver clauses for protecting individuals against flaws associated with arbitration might lead the Supreme Court formally to accord deference to arbitral determination of "questions of fact," while preserving the judiciary's plenary power over "questions of law."

is Id. at 60 n.21.

1" United Steelworkers of America v. American Mfg. Co., 363 U.S. 564 (1960); United Steelworkers of America v. Warrior \& Gulf Navigation Co., 363 U.S. 574 (1960); United Steelworkers of America v. Enterprise Wheel \& Car Corp., 363 U.S. 593 (1960).

"See McKelvey, supra note 1, at 28.

in Newman, supra note 10, at 37 . 
These justifications seem deficient for three principal reasons. First, these expansionist proposals understate the extent to which arbitrators are already authorized under conventional contractual clauses to deal with claims cognizable under Title VII. ${ }^{19}$ Second, the incremental jurisdiction to invalidate specific contractual clauses that the expansionist clauses would confer is, I believe, incompatible with the nature, procedures, and essential logic of the arbitration system and would place serious strains on that system. Third, the exercise of such jurisdiction would be unlikely to ease the burdens of the federal judiciary.

I turn first to the extent to which conventional contractual clauses cover issues that substantially overlap or coincide with Title VII issues. Even though an agreement lacks a no-discrimination clause, provisions such as those requiring just cause for discipline, or job-related qualifications for promotion, would be violated if race or sex had entered into an employer's decisions. The inclusion in an agreement of terms as elastic as just cause is presumably designed to permit arbitral consideration of the developing, as well as the established, norms and values of the community. ${ }^{20}$ Although legislation, such as Title VII, may reinforce or crystallize such values, it is not a prerequisite for considering them. For example, new attitudes regarding dress, speech, drugs, homosexuality, or premarital heterosexual relations are likely to impinge on arbitration regardless of whether those attitudes are reflected in legislation. Contractual standards such as just cause are formulated loosely, presumably in order to permit the arbitrator to consider all relevant factors, including those values embodied in statutes and the Constitution-values that help shape standards of justice not only in the plant, but also in the larger community. ${ }^{21}$

19 This understatement has been stimulated by what, in my opinion, was a mistaken implication in the Supreme Court's opinion in Gardner-Denver. The Court recognized that the same question may arise under Title VII and a collective bargaining agreement when an agreement's provisions track those of Title VII. See 415 U.S. at 55. It is not clear, however, that the Court also recognized that such an identity of issue might arise solely from broad contractual provisions, such as "just cause." See Meltzer, The Impact of Gardner-Denver on Labor Arbitration, in Proceedings of New York UnIversity Twenty-Seventh ANNuAl ConFERENCE ON LABOR 189, 191-92 (1975); cf. Electronic Reproduction Serv. Corp., 213 N.L.R.B. 758 (1974).

${ }^{20}$ See Meltzer, Labor Arbitration and Overlapping and Conflicting Remedies for Employment Discrimination, 39 U. CHI. L. Rev. 30, 31-32 (1971).

${ }^{21}$ See also Southern Airways, Inc., 47 Lab. Arb. 1135, 1141 (1966) (Wallen, Arbitrator), discussed in McKelvey, supra note 1, at 15. This point is a pervasive one; it applies not only to collective agreements but to all agreements containing malleable standards, such as the good faith standard embodied in some commercial agreements. 
Unlike Gardner-Denver clauses, conventional clauses that can fairly be said to absorb the values underlying a regulation do not require that all elements of the regulation be inflexibly imported into the parties' bargain. Thus, a contract examined in the light of Title VII may be read as prohibiting consideration of race or sex in promotion without necessarily requiring that an arbitrator look to the law under Title VII in defining the elements of a prima facie case, or in determining the admissibility or weight of statistical evidence in connection with a grievance over a promotion. ${ }^{22} \mathrm{~A}$ Gardner-Denver clause, by contrast, appears to be designed to bind the arbitrator completely to the body of Title VII law, or at least its substantive if not its procedural elements.

As a consequence, Gardner-Denver clauses would appear to require the arbitrator to invalidate specific contractual clauses found to be repugnant to Title VII and, accordingly, to contend with the validity of contractual clauses such as these:

(1) Seniority provisions or their applications, when they are challenged as contrary to one or more of the following: Title VII, a conciliation agreement or a consent decree under that title, an EEOC guideline, an affirmative action program.

(2) Provisions dealing with disability payments, or paid or unpaid leaves of absence, in connection with pregnancy or maternity.

(3) Provisions calling for the use of aptitude tests.

(4) Provisions calling for equal retirement contributions on behalf of men and women and resulting in lower annual benefits to women because of their greater longevity.

Arbitral invalidation of such clauses would involve special strains; for it would nullify the consensus reflected in the parties' specific arrangements. Although the Gardner-Denver clause purportedly bases such nullification on the parties' consent, there is a special risk that this ostensible consent will be formal rather than real. ${ }^{23}$

${ }^{22}$ See, e.g., IAM Lodge 2476 (Sisk Case No. 204-1 AAA) ("[C]harges (based on statistics) are a matter of substantive law and beyond the scope of the agreement"); cf. Olson v. Philco-Food, 12 FEP Cas. 426 (10th Cir. 1976).

${ }^{23}$ The "consent" will of course be spurious if a broad no-discrimination clause is a response to OFCC guidelines or similar governmental pressures. It is true that agreement in the context of collective bargaining is often the result of direct economic pressure. But the problem of consent raised by Gardner-Denver clauses is different in two significant and destabilizing respects. First, such clauses are likely to involve conflict with the particularized arrangements hammered out by the parties. Second, when arbitrators, pursuant to such clauses, deal with questions of external law, their determinations are subject to the plenary authority of the judiciary. 
Indeed, the incremental jurisdiction conferred by such clauses would cover issues that go beyond not only the core values of Title VII but also beyond any clear consensus in the plant or the larger community.

Those issues involve the extent to which our national policy does, and may constitutionally, embrace equality of outcomes, and not merely equality of opportunity, for different groups. In this connection, the Attorney General of the United States recently observed, "A law against discrimination hovers on the edge of becoming a law for discrimination, not to correct past wrongs but because society is seen, not as composed of individuals with talents and rights, but as a series of groups vying for power." ${ }^{24}$ Others have argued that we have already gone over that edge..$^{25}$ But the Civil Rights Commission ${ }^{26}$ and other respected voices sound the other horn of this national dilemma and urge that enforcement of the law of equal opportunity has been inadequate and underinclusive.

If the awesome issues inherent in this dilemma are to be resolved in adjudication, the appropriate tribunal appears to be, and ultimately will be, the courts and not private adjudicators. The fundamental inadequacy of arbitration as a forum for resolving these issues is the second reason for disfavoring expansionist clauses. As the Supreme Court observed in Gardner-Denver, those ingredients of arbitration that make it such a valuable adjunct to a system of private ordering, compromise it as an instrument of important public purposes. ${ }^{27}$ These ingredients are arbitration's informality, its privacy, its emphasis on finality at the trial level, the ad hoc recruitment of its personnel, and the ecumenical nature of their credentials. Arbitrators, no matter how great their individual competence, lack the institutional credentials that give moral authority to the decisions of the federal judiciary. ${ }^{28}$ That authority arises from a complex of tradition and process, including selection processes, the solemnity with which judges typically function, the publicity of their forum, the respectability and expectation of appellate review, and lifetime tenure. Indeed, there is an ironic twist in attempting to provide by contract that ad hoc arbitrators-the most ephemeral

${ }^{24}$ E. Levi, In the Service of the Public, Feb. 14, 1976 (address to the Fellows of the American Bar Foundation in Philadelphia, Pa.).

${ }^{25}$ See N. Glazer, Affirmative Discrimination (1975).

265 U.S. Comm'n on Civil Rights, The Federal Civil Rights Enforcement EFFoRT-1974, at 617-18, 649 (1975).

27 See 415 U.S. at 57-58.

${ }^{28}$ See Meltzer, supra note 20, at 34-35. 
of adjudicators-should have the same authority as life-tenured federal judges.

Supplementing these symbolic and traditional considerations are the more tangible difficulties that would be involved in the exercise of incremental jurisdiction under Gardner-Denver clauses. Such jurisdiction would, as previously suggested, encompass socalled systemic discrimination resulting from facially neutral arrangements that frequently appear to be free from any specific intention to discriminate. Cases in which such discrimination is alleged tend to involve extensive discovery, intervention by various groups, long trials, and uncertainty regarding the governing law. Such disputes would place special strains on arbitral procedure, which is designed to be quick, informal, and inexpensive.

Another and more important institutional consideration is that the attempt by arbitrators to resolve the general legal questions arising under Gardner-Denver clauses might well compromise the achievement of the paramount purposes of arbitration and no-strike clauses-industrial peace, fairness, and order. Labor arbitration is, of course, a substitute not merely for court action but preeminently for economic warfare..$^{29}$ The relative success of conventional arbitration arrangements is directly dependent on such factors as the genuineness of the consensus reflected in the parties' agreement and the finality that typically attaches to the arbitrator's award. In contrast, awards based on the incremental jurisdiction granted by a Gardner-Denver clause lack the support of these key factors and may ultimately weaken confidence in and acceptance of the results of arbitration. ${ }^{30}$

Quite apart from those risks, clauses granting such incremental jurisdiction to arbitrators are not likely to help relieve the overloaded dockets of the EEOC and the federal courts. ${ }^{31}$ Arbitrators

29 See Feller, A General Theory of the Collective Bargaining Agreement, 61 CALIF. L. REv. 663,817 (1973).

so The foregoing institutional objections to Gardner-Denver clauses would also apply to the antidiscrimination clause required under the current OFCC guideline if that guideline were viewed as requiring a broader clause that would be enforced by arbitration and would serve as a basis for invalidating other specific provisions of the agreement. Of course, if that guideline would be satisfied merely by a clause under which a nondiscrimination standard is to infuse the application of the other provisions of an agreement, it would be wholly appropriate to have that standard enforced through the contractual grievance procedures. Indeed, any effort to withhold arbitration from grievances that are cognizable under the agreement merely because these same grievances were cognizable under Title VII would give rise to legal difficulties. See text at notes 34-36 infra.

${ }^{31}$ The percentage of these dockets generated by the unionized sector-the primary consumer of arbitral services-has not, to my knowledge, been determined; thus the extent to 
under conventional agreements typically have jurisdiction over many grievances as to which the specific provisions of the collective agreement and title VII are in accord. Such grievances include those arising from complaints that race or sex entered into individual employment decisions, such as promotions or discharges. Furthermore, the key questions raised by such grievances are factual, and, under Gardner-Denver, arbitral determinations of issues of fact may be given great weight by the courts, even though they in effect reject the claim of discrimination. If similar weight were accorded such arbitral determinations by the EEOC and other administrative agencies, multiple litigation on questions of fact would be discouraged. The expansionist clauses are, of course, designed to expand the arbitrator's jurisdiction to include general questions of law, such as the validity under Title VII of seniority provisions or other contractual provisions. But it is with respect to precisely these questions that arbitrators lack any special competence. There is, accordingly, no reason why their awards should receive special deference from courts or the losing party. In some situations, there may, of course, be strong practical pressures on a losing party to acquiesce in what seems to be an erroneous arbitral determination of a question of external law. But such pressures and acquiescence will be less likely when a part of the parties' bargain is being invalidated. In any event, without formal deference from the courts or de facto deference by the losing party, the prospect that expansionist clauses will help reduce the backlogs of official tribunals is remote indeed.

The parties could improve that prospect by purporting to grant an arbitrator final and binding authority to nullify or rewrite elements of their agreements in order to bring it into compliance with Title VII and related regulations; they could also authorize him to go beyond the minimum requirements of that law. Courts would presumably uphold such agreements and give finality to resultant awards provided that they met minimum legal requirements. In other words, the parties could commission arbitrators to serve as their joint legal advisors or as their compliance officers, for the purpose of Title VII and related regulations. But the grant of arbitral authority to go beyond the requirements prescribed by Title VII would be extraordinary and should not be lightly inferred. ${ }^{32}$ Under

which granting incremental jurisdiction would reduce resort to official tribunals may be insignificant.

${ }^{32}$ Indeed, when the arbitrability question involves the arbitrator's authority to deal with a question of external law, the presumption in favor of arbitrability announced in the Steelworkers trilogy should not be applicable, since the presumption rests on the superior 
Gardner-Denver clauses and most contractual clauses it seems likely, therefore, that arbitral resolutions of general questions of law would be denied deference whether they were attacked in court as exceeding, or as falling below, minimum statutory requirements. In either event, the official tribunal would have to make an independent determination as to the requirements of external law.

It has also been suggested by proponents of Gardner-Denver clauses that judicial deference to arbitral awards might be achieved-or at least made more likely-by setting up panels of arbitrators certified as specially qualified for discrimination cases by the EEOC or by organizations such as NOW or the NAACP. ${ }^{33}$ Such certification by enforcement tribunals or partisan organizations, however worthy, is a strange prerequisite for those who are to serve as surrogates for federal judges. ${ }^{34}$ In any event, it is doubtful that even such screening would lead to the formal judicial deference denied in Gardner-Denver. ${ }^{35}$

The adoption of these expansionist proposals is not likely, then, to curb relitigation or to reduce the Title VII backlog. In addition, the adoption of such proposals might have perverse results, in that arbitrators would be working on cases in which relitigation was likely at the possible expense of cases in which their awards had a greater chance of being final in fact. ${ }^{36}$

I do not mean to minimize the need to attack the Title VII backlog as well as the remedial proliferation and disarray in discrimination cases. I suggest only that the problem is too big for Gardner-Denver clauses, and they may do more harm than good ${ }^{37}$

Equally dubious is another type of proposal also spawned by

competence of the arbitrator to deal with contractual, as distinguished from statutory, questions. See Western Mass. Elec. Co., 65 Lab. Arb. 816, 821-22 (1975) (Summers, Arbitrator).

"see Newman, supra note 10, at 37-38.

3: The FMCS has declined, wisely I believe, to compile such specialized lists. See 90 LaB. REL. REP. 285-86 (1975).

"Ss See note 14 supra. The Court in Gardner-Denver stated that "there can be no prospective waiver of an employee's rights under Title VII." 415 U.S. at 51; cf. Basic Vegetable Prods., Inc., 64 Lab. Arb. 620, 621 n.1 (1975) (Gould, Arbitrator).

3t These proposals might divert scarce arbitral resources from cases in which the contractual and statutory questions coincide to cases in which the arbitrator is, in effect, being asked to invalidate a contractual provision as being repugnant to the statute. In the former class of cases, where the key issues are likely to be factual, arbitral determinations might receive great weight under Gardner-Denver. In the second class of cases, the questions are manifestly issues of external law, and there is no basis for attaching great weight to arbitral determinations of such questions.

"An even more difficult question can be only mentioned here, i.e., whether additional resources for enforcing Title VII, including additional federal judges, would be largely neutralized by an increased flow of cases. The vast number of employment decisions that may give rise to plausible claims under Title VII raises familiar questions about the "limits of effective 
the Gardner-Denver decision: the so-called limitist proposals. These proposals would exclude from arbitration grievances that are cognizable under Title VII. One variation would unconditionally exclude any claim asserting that race or sex entered into the employer's breach of the agreement. A less absolute variation would bar arbitration of a claim if it had been filed with a governmental tribunal. Such proposals are apparently designed to protect employers against double jeopardy with respect to the same basic claim of discrimination. Although that purpose is an appealing one, there is reason to doubt the legality as well as the desirability of such limitist clauses.

With regard to the first type of limitist clause, one objection is that the total exclusion of overlapping Title VII claims from arbitration might well be discrimination invalid under that title, ${ }^{38}$ as an EEOC district director has held. ${ }^{39}$ Second, a union's acquiescence in such exclusion would arguably violate the union's duty of fair representation. ${ }^{40}$ Each of those objections would gain some support from the Supreme Court's recognition, in Gardner-Denver itself, ${ }^{41}$ of arbitration's usefulness in resolving claims of discrimination. Third, Title VII issues, including emerging issues of "reverse discrimination," are so pervasively intertwined with ordinary contractual issues that exclusion of arbitration in situations involving a congruence of statutory and contractual claims would drastically curtail the scope of arbitration. Such exclusion, relegating aggrieved employees to the slower statutory remedies, might increase the propensity of employees to engage in self-help in violation of no-strike clauses. Employees are not wholly unaware of the link between a nostrike clause and the existence of orderly alternatives for resolving disputes. Furthermore, curtailing the scope of arbitration would endanger specific enforcement of a no-strike clause since the underlying grievance would be nonarbitrable.42

A similar weakening of the psychological and legal underpinnings of the no-strike obligation would probably accompany limitist

legal action"- at least through civil adjudication and without effective means for discouraging frivolous claims and defenses. See A. Bickel, The Morality of Consent 106 (1975).

38 See Meltzer, supra note 20, at 34.

${ }^{39}$ See Bentley v. Westinghouse Elec. Co., No. YNYI-260, TNYO-0460 (EEOC, Nov. 27, 1972), summarized in Newman, supra note 10, at 39. See also Basic Vegetable Prods., Inc., 64 Lab. Arb. 620, 625 (1975) (Gould, Arbitrator).

to See authorities cited notes 20-21 supra.

"See 415 U.S. at 55.

${ }^{12}$ See Buffalo Forge Co. v. United Steelworkers of America, 44 U.S.L.W. 5346 (U.S. July 6, 1976); Boys Markets, Inc. v. Retail Clerks Local 770, 398 U.S. 235, 251-54 (1970). 
clauses of the second type, which preclude arbitration of claims filed with official agencies. This conditional form of limitation is less objectionable than the unconditional exclusion from arbitration of all Title VII grievances; for it would bar an aggrieved employee from arbitration only if he had chosen an alternative forum. Not surprisingly, therefore, at least one state court has upheld such a clause as consistent with Gardner-Denver. ${ }^{43}$

These objections to the limitist proposals are not meant to minimize the familiar difficulties of multiple litigation. There is not, to my knowledge, any reliable information concerning the extent to which arbitral rejections of discrimination claims have been relitigated in the post-Gardner-Denver period. Members of the bar claim that regional offices of the EEOC frequently deny any weight to such arbitral determinations and that state agencies take a similar position. As a consequence, employers tend to settle unmeritorious claims, in order to avoid expensive litigation. To the extent that the foregoing description of the administrative-settlement process is accurate, the significant relitigation would not reach the federal courts. The extent of such hidden relitigation and the effect given to arbitration awards by the EEOC and its state counterparts are obviously important questions that warrant investigation.

Recent arbitration decisions document the foregoing apprehensions about arbitrators applying external law. In dealing with conficts between external law and contractual provisions, arbitrators, according to Feller's careful summary, appear to follow Mittenthal's approach, at least where the law is clear:44 they look to the law rather than the contract when an employer seeks to justify action that he has taken in violation of the contract on the ground that his action was required by law. Arbitrators, it is said, generally will not order the employer to take action that would violate the law. ${ }^{45}$ But arbitrators apparently look to the contract rather than the law when

${ }^{43}$ Board of Higher Educ. v. Professional Staff Congress/CUNY, 80 Misc. 2d 297, 362 N.Y. Supp. 2d 985 (Sup. Ct. 1975); cf. Guthrie v. Texaco, Inc., 80 L.R.R.M. 297 (S.D.N.Y. 1975) (an employee who has filed an action against his employer for personal injuries was barred from arbitrating the same claim after the employer files an answer). Nevertheless, such an exclusionary clause might be viewed-albeit somewhat implausibly - as inconsistent with the spirit of the no-reprisal section of Title VII, 42 U.S.C. $\$ 2000 \mathrm{e}-3(\mathrm{a})$, and especially so if employees who had invoked statutes other than Title VII, such as OSHA, were not required to forgo arbitration of the same claim.

"See Feller, supra note 1; Mittenthal, The Role of Law in Arbitration, in Developments in American and Foreign Arbitration: Proceedings of the Twenty-First Annual Meeting, National Academy of ARBitrators 42, 50 (1968).

${ }^{t 5}$ See, e.g., Copolymer Rubber \& Chem. Corp., 64 Lab. Arb. 310, 314 (1975) (Dunn, Arbitrator). 
the employer has followed the agreement, and the claim is that he should have followed the law. The critical difference, then, is between the legal bird in the hand and the one in the bush. This distinction is not without its conceptual difficulties. ${ }^{46}$

Even more troublesome are the serious practical difficulties in determining what the law is. Thus, as Feller indicates, arbitrators confronted with open legal questions have sometimes shown a genius for false predictions in dealing, for example, with the interaction of collective bargaining agreements, state protective legislation and Title VII. ${ }^{47}$ In addition, some arbitral decisions raise serious questions about the proper sources of overriding law. Should recommendations by OFCC compliance officers ${ }^{48}$ as to the affirmative action appropriate for a particular employer be considered "law," triggering the doctrine of supervening impossibility? Fortunately, some arbitrators say "no."49 Should EEOC guidelines in general be considered law? $?^{50}$ Or is the forceful rejection of that position in Millinocket School Committe ${ }^{51}$ closer to the truth? It is worth not-

"I I have adverted to these difficulties elsewhere. See Meltzer, The Role of Law in Arbitration: A Rejoinder, in Developments in American and Foreign Arbitration: Proceedings of the Twenty-First Annual Meetings, National Academy of Arbitrators 58 (1968).

17 See Feller, supra note 1. Trial courts have, of course, experienced similar difficulties, but they are not part of a system that emphasizes the importance of avoiding review of even "erroneous" decisions.

17 See ASG Indus., Inc., 62 Lab. Arb. 849 (1975) (Foster, Arbitrator). But cf. Hollander \& Co., 64 Lab. Arb. 816 (1975) (Edelman, Arbitrator):

19 See Diamond Power Specialty Corp., 66 Lab. Arb. 729, 735-36 (1976) (High, Arbitrator); Day \& Zimmermann, Inc., 60 Lab. Arb. 495 (1973) (Marcus, Arbitrator); Coulson, Title Seven Arbitration in Action, 27 LAB. L.J. 141, 149 (1976). See generally RestatemENT of Contracts § 458 (1932).

so See Goodyear Tire \& Rubber Co. v. Local 200, Rubber Workers, 42 Ohio St. 2d 516, 521,330 N.E. $2 \mathrm{~d} 703,707$ (1975). The court upheld the arbitrator's modification of a contractual provision regarding pregnancy-disability despite the ambiguity of the award as to whether an EEOC "guideline" constituted a "regulation." The court dismissed its own view on the merits as irrelevant, urging that the Steelworkers trilogy restricted judicial review. Thus the legal question underlying the grievance apparently was not squarely confronted by either the arbitrator or the court despite differences among government agencies and uncertainties reflected in Supreme Court opinions as to the force to be given to EEOC guidelines. See statement of Carl Goodman, General Counsel of U.S. Civil Service Comm'n, 91 LaB. REL. REP. 108 (1976); Albemarle Paper Co. v. Moody, 422 U.S. 405 (1975); Espinoza v. Farah Mfg. Co., 414 U.S. 86, 94-95 (1973).

51 Whatever might be the leanings of the Equal Employment Opportunity Commission regarding the pregnancy-sick leave question, they are not binding upon this or any other arbitrator. The interpretative bulletins of such governmental agencies do not constitute law. Such opinions are transitory, and subject to sudden and frequent changes due to the tendency of governmental agencies towards the broadest kind of preemption and authority. Their reach is always greater than their grasp in the belief that the courts are always there to correct any excesses in which they might indulge themselves.

65 Lab. Arb. 805, 810 (1975) (Purcell, Arbitrator). 
ing that when EEOC guidelines are treated as law in arbitration, there is a risk that they will escape the scrutiny of the arbitrator and, upon review, of a court relying mistakenly on the finality accorded to contractual determinations under the Steelworkers trilogy. ${ }^{52}$ Presumably this bootstrap operation will disappear with increased sophistication regarding the nature of the guidelines as well as the limitations on the deference decreed by the Steelworkers trilogy. Finally, arbitral awards point up a genuine risk that conciliation agreements ${ }^{53}$ and consent decrees will be invoked to supersede contractual rights without regard to whether the party adversely affected had a right to participate in prior proceedings. ${ }^{54}$

This article has emphasized the difficulties inherent in authorizing arbitrators to invalidate specific contractual arrangements that are contrary to Title VII. Despite such difficulties the parties may in some situations seek to go beyond the Supreme Court's view of arbitration as a limited tool of self-government. For they may have a strong desire to obtain from a single body answers to all the interrelated problems of a single dispute, including problems of external law; they may thus ask arbitrators to determine legal questions, albeit subject to plenary review by the federal courts. Ultimately the parties will, of course, decide whether the special risks of such arbitral determinations should be taken. But their decision in this context, whatever its nature, should not become a measure of their commitment to the goal of equal employment opportunity. For the underlying problem is not one of substantive policy, but of the distribution of authority between the parties' machinery and that of the state.

In recent years we have heard much about failures to respect

52 See note 50 supra.

${ }^{3}$ See Lockheed Missiles \& Space Co. v. Machinists Lodge 508, 72-1 CCH Lab. Arb. Awards ๆ 8360 (1972) (Koven, Arbitrator). But cf. Virginia Elec. \& Power Co., 61 Lab. Arb. 844 (1973) (Murphy, Arbitrator).

In Southbridge Plastics Div. v. Local 759, Rubber Workers, 403 F. Supp. 1183 (N.D. Miss. 1975), the court, in an action in which the union, as well as the employer and the EEOC, was a party, subordinated seniority provisions to a conciliation decree, but the court made an independent determination that those provisions contravened Title VII.

s4 For a discussion of the protection of such rights in the discrimination context, see Kilberg, Current Civil Rights Problems in the Collective Bargaining Process: The Bethlehem \& AT\&T Experiences, 27 VAND. L. Rev. 81, 101-05 (1974); United States v. Allegheny-Ludlum Indus., Inc., 517 F.2d 826, 845 \& n.20 (5th Cir. 1975). See also McAleer v. AT\&T Co., 12 FEP Cas. 1473 (D.D.C. 1976) (allowing damages to male employee denied promotion to which he was entitled under collective agreement because of employer's compliance with affirmative action program for the promotion of females that was part of a consent decree; neither the union nor the employees were a party to the consent decree, and accordingly they were not barred by the decree from suing for breach of contract). 
the essential limitations of office. Indeed, for arbitrators, there is a cautionary tale in the fact that the word "imperial" as applied to governmental organs has become a reigning cuss word. As exotic tasks are being considered for arbitration, as arbitral associations look for new worlds to conquer, as arbitrators contemplate new opportunities for service and fees, the spirit of our time invites us to ponder the limitations that appear to have helped make labor arbitration such a successful invention. At the same time, absolutist positions that would completely foreclose even well-informed parties from enlisting advisory arbitration regarding issues of external law invite us to recall the remarkable flexibility of the machinery of arbitration as well as the parties' right to limit or to enlarge its scope. 